\title{
Removal of Orange G Dye from Aqueous Solution by Adsorption: A Short Review
}

\author{
Saifullahi Shehu Imam ${ }^{1 *}$, Atika Ibrahim Muhammad ${ }^{1}$, Halimah Funmilayo Babamale², \\ Zakariyya Uba Zango ${ }^{3}$
}

\author{
${ }^{1}$ Department of Pure and Industrial Chemistry, Bayero University, P.M.B 3011, Kano State, Nigeria \\ ${ }^{2}$ Department of Industrial Chemistry, University of Ilorin, P.M.B 1515, Kwara State, Nigeria \\ ${ }^{3}$ Department of Chemistry, Al-Qalam University, P.M.B 2137, Katsina State, Nigeria
}

Received: 29/08/2020

Accepted: 28/11/2020

Published: 20/03/2021

\begin{abstract}
Adsorption is a widely used technique for wastewater remediation. The process is effective and economical for the removal of various pollutants from wastewater, including dyes. Moreover, Besides commercial activated carbon, different low-cost materials such as agricultural and industrial wastes are now used as adsorbents. The present review focused on the removal of a teratogenic and carcinogenic dye, orange $\mathrm{G}(\mathrm{OG})$ via adsorption using several adsorbents, together with the experimental conditions and their adsorption capacities. Based on the information compiled, various adsorbents have shown promising potential for OG removal.
\end{abstract}

Keywords: Adsorption, Orange G dye, Adsorbents, Wastewater treatment

\section{Introduction}

Human and animal protection has been disrupted due to water contamination as a result of numerous pollutants discharged from various industries (1). Among the most common contaminants found in the water, those from organic origins have been found to exert hazardous effects due to their accumulative and persistent nature in water. Dyes have been recognized as the most frequent organic pollutants found in the water due to their wide applications in various industries such as textile, cosmetics, leather and petrochemical (2). They are recognized as emerging contaminants due to their resistant nature of undergoing natural degradations. In fact, United States Environmental Protection Agency (USEPA) has listed organic dyes and pigments as hazardous substances (3). Orange $\mathrm{G}(\mathrm{OG})$ belongs to the class of azo dyes of synthetic origin. It is a form of mono azo and anionic dye, which is soluble in water and stable at any $\mathrm{pH}$ (4). It is usually present as a sodium salt in two tautomeric forms in aqueous solution, while organic solvents favour the azo form (5). It has been used for a long time in United States of America for various applications such as medication and as a colorant for cosmetics before it was subsequently abandoned (6). Currently, it is used in textile and printing industries for dyeing of materials (such as silk and wool), paper and leather productions etc. (7). Furthermore, OG is also used in histology in many staining formulations and is likewise essential to pathologists (8). The colour of OG is due to the azo group, while the auxochromes $\left(-\mathrm{SO}_{3},-\mathrm{OH}\right.$, etc.) enhances the affinity of the dye (9). The azo bonds are being adsorbed onto the surface of an adsorbent through a covalent bond, which makes it more resistant to harsh conditions (10). The physicochemical properties and molecular structure of OG are highlighted in Table 1.

\subsection{Toxicity of $O G$}

OG dye has been found to exert hazardous and inevitable harmful effects on aquatic species and the entire water environment $(4,11)$. It has been reported as one of the highly poisonous anionic dye, which shows some chromosomal damage and clastogenic activity $(12,13)$. Its toxic, carcinogenic and teratogenic effects to the living organisms has been attributed to the azo group in its chemical structure (14-16). Not only OG, but the intermediates formed during its degradation are also toxic too (17). OG is likewise harmful to plants, flora and fauna (18). Furthermore, for humans, exposure to OG may result in irritation of the gastrointestinal and respiratory tract (7). It has also shown genotoxic effects on experimental animals such as Swiss albino mice and anaerobic biomass in aqueous solution $(8,19)$.

\section{Environmental remediations of $\mathrm{OG}$}

Owing to the various adverse effects of OG on humans, aquatic organisms as well as plants, researchers have embarked on exploring different wastewater remediation techniques for the removal of this toxic pollutant in the environmental waters. Various technologies such as coagulation (20), flocculation (21), bioremediations (22), photocatalytic degradations (23) as well as physical adsorptions (24) have been reported in wastewater treatment. The use of physical adsorption has been highly recognized as an effective wastewater remediation method due to its promising properties ranging from the availability of various adsorbent materials, cost-saving, simplicity of design, flexibility as well as the non-destructive environmental nature of the method. Moreover, adsorption has been identified by USEPA as one of the best control methods (25). As such, this short review is aimed at exploring various adsorbent materials used for the removal of OG.

Corresponding author: Saifullahi Shehu Imam, Department of Pure and Industrial Chemistry, Bayero University, P.M.B 3011, Kano State, Nigeria. E-mail: ssimam.chm@buk.edu.ng 
Table 1: Physicochemical properties and molecular structure of OG

\begin{tabular}{|c|c|c|}
\hline Property & Orange G (OG) & Reference \\
\hline Chemical formula & $\mathrm{C}_{16} \mathrm{H}_{10} \mathrm{~N}_{2} \mathrm{Na}_{2} \mathrm{O}_{7} \mathrm{~S}_{2}$ & $(26)$ \\
\hline Chemical name & 7-hydroxy-8-(phenylazo)-1,3-naphthalenedisulfonic acid disodium salt & $(27)$ \\
\hline Generic name & Acid Orange 10 & (27) \\
\hline Abbreviation & $\mathrm{AO} 10$ & (28) \\
\hline C.I. & 16230 & (26) \\
\hline CAS number & $1936-15-8$ & (29) \\
\hline Classification & Azo dye & (26) \\
\hline Colour & Orange & $(30)$ \\
\hline$\lambda_{\max }$ & $475 \mathrm{~nm}$ & (26) \\
\hline Log P (octanol-water) & -4.56 & (29) \\
\hline $\mathrm{pKa}$ & 11.5 & (29) \\
\hline Molecular size $\left(\AA^{3}\right)$ & $13.08 \times 7.53 \times 4.98$ & (31) \\
\hline Molecular weight $\left(\mathrm{gmol}^{-1}\right)$ & 452.37 & (26) \\
\hline Henry's law constant & $5.86 \mathrm{E}-0.23 \mathrm{~atm}-\mathrm{m}^{3} / \mathrm{mole}$ & (29) \\
\hline $\begin{array}{l}\text { Atmospheric } \mathrm{OH} \text { rate } \\
\text { constant }\end{array}$ & $1.49 \mathrm{E}-0.12 \mathrm{~cm}^{3} /$ molecule-sec & (29) \\
\hline Dye content $(\%)$ & 90 & (26) \\
\hline Melting point & $141^{\circ} \mathrm{C}$ & (32) \\
\hline Water solubility & $5 \mathrm{~g} / 100 \mathrm{~mL}\left(20^{\circ} \mathrm{C}\right)$ & (32) \\
\hline Chemical structure & & (26) \\
\hline
\end{tabular}

\section{Adsorbents used for OG removal \\ 3.1 Biomass-based adsorbents}

The use of biomass as adsorbents for wastewater remediation has been widely explored. Biomass is renewable energy derived from plant and animal organic matter (33). They offered numerous advantages as an alternative to other adsorbents used due to their natural occurrence, relative abundance and existence in various forms, as well as the lowcost. Various studies have reported the use of several biosorbents for the biosorption of OG dye. For instance, Ari and Celik (34) investigated the biosorption potential of both pristine and hegzadecylethyldimethylammonium bromide (HDEDMABr) modified Pyracantha coccinea ( $P$. coccinea) towards the removal of $\mathrm{OG}$ dye from aqueous solution. Initially, pristine $P$. coccinea had a biosorption capacity of 4.55 $\mathrm{mg} / \mathrm{g}$. However, its capacity increased to $90.16 \mathrm{mg} / \mathrm{g}$ after modification with HDEDMABr. Furthermore, Hsini, Essekri (35) prepared a biocomposite (PANI@AS) by coating almond shell (AS) using polyaniline (PANI) and used as adsorbent for the removal of OG dye from aqueous solution. The adsorption of OG dye using PANi@AS reaches equilibrium within 90 min, and the process was spontaneous and endothermic.

The use of modified rice husk char (RHC) using $\mathrm{KOH}$ (KMRHC) as an adsorbent for the removal of OG dye has been reported by Malik, Khan (36). KMRHC could almost completely removed OG dye from aqueous solution, as the removal efficiency reached $96 \%$, in a process that was spontaneous and exothermic. Also, acid modified wheat husk was used by Banerjee et al. (37) as an adsorbent for the removal of OG dye. Low $\mathrm{pH}$ was found to enhance the adsorption of OG dye onto acid-modified wheat husk and equilibrium was attained within $30 \mathrm{~min}$. The percentage of dye removal was found to increase with adsorbent dosage, contact time and ionic strength, but diminished slightly with increase in temeperature and initial OG concentration. Maximum adsorption capacity was found to be $31.25 \mathrm{mg} / \mathrm{g}$ and the experimental data fitted well with the Freundlich adsorption isotherm and pseudosecond-order Kinetic model. Thermodynamic study revealed that the adsorption process is spontaneous and exothermic. In a different study, Kumar, Ahluwalia and Charaya (38) made use of powdered biomass of Chlorela vulgaris as adsorbent for the removal of $\mathrm{OG}$ dye from aqueous solution. Maximum performance was recorded using $50 \mathrm{mg} / \mathrm{mL}$ biomass dosage. Optimum $\mathrm{pH}$, temperature and time were found to be $5,10^{\circ} \mathrm{C}$ and $10 \mathrm{~min}$. The experimental data fitted the Freundlich isotherm model (38). Tobacco leaves (TL) were also used by Mohammed and Al-Mammar (39) as adsorbents for the removal of OG from aqueous solution. The maximum removal of OG using TL was recorded at $\mathrm{pH}$ of 9 and 10 , and adsorption reaches saturation in $140 \mathrm{~min}$.

\subsection{Activated carbon-based adsorbents}

Several studies have reported the use of activated carbon (AC) for the removal of OG dye from aqueous solution. In general, AC is the most widely used sorbent for both environmental and industrial applications (40). This is due to its large surface area and ability to adsorb a wide range of organic compounds (41). Furthermore, any carbonaceous material of plant or animal origin with high carbon concentration can be used for the production of AC (42). For instance, Arulkumar, Sathishkumar (43) studied the performance of AC prepared via chemical activation of Thespesia populnea pods using sulphuric acid for the removal of OG dye from aqueous solution. The maximum adsorption capacity was found to be $9.129 \mathrm{mg} / \mathrm{g}$ and the experimental data fitted well with the Freundlich isotherm and pseudo-second- 
order reaction kinetics model. In the case of Laksaci, Khelifi (44), raw coffee ground was used as a precursor to prepare AC for subsequent use as adsorbent for the removal of OG dye. The $\mathrm{AC}$ produced was found to be microporous with a specific surface area of $1455 \mathrm{~m}^{2} / \mathrm{g}$, and the adsorption process was spontaneous and endothermic. Furthermore, Goswami and Phukan (45) also prepared AC using matured tea leaf (MTLAC). Subsequently, the surface of MTLAC was modified by incorporating sulfonic acid to form MTLAC-SA. This resulted in the decrease of pHpzc value from 5.18 in the case of MTLAC to 2.48 in the case of MTLAC-SA. Despite such modification, the adsorption capacity of MTLAC towards OG dye was still higher than that of MTLAC-SA. Apart from pristine $\mathrm{AC}$, composites consisting of $\mathrm{AC}$ and other adsorbents have also been used for the removal of OG from aqueous solution. For instance, Saini, Garg (26) deposited $\mathrm{ZnO}$ on AC to form $\mathrm{ZnO}-\mathrm{AC}$ nanoparticles for subsequent use as adsorbents for the removal of $\mathrm{OG}$ in bath mode. The nanoparticles were found to have a maximum adsorption capacity of $153.8 \mathrm{mg} / \mathrm{g}$ for $\mathrm{OG}$, and the adsorption process was exothermic. Another composite was prepared by Jalali, Rahimi (46) via loading $\mathrm{SnO}_{2} /\left(\mathrm{NH}_{4}\right)_{2}-\mathrm{SnCl}_{6}$-NCs onto $\mathrm{AC}$ and used for the removal of OG. The composite had a pHpzc of 6.0 and was able to remove up to $97.0 \%$ of OG.

\subsection{Clay-based adsorbents}

Several clays have been used as adsorbents for the removal of various pollutants, including OG. For instance, Dawood (47) made use of bentonite as adsorbent for the removal of OG. The equilibrium time for the adsorption of OG using bentonite was found to be dependent on the adsorbate concentration. Still, the percentage removal of OG using bentonite increased with a decrease in temperature, an indication that the process was exothermic. Apart from pristine clay, studies have reported the use of modified clays as adsorbents for the removal of OG. For instance, Jović-Jovičić, Milutinović-Nikolić (48) modified a local bentonite using hexadecyl trimethylammoniumbromide (HDTMA-bromide) to produce HDTMA-bentonite. Compared to Na-bentonite, the adsorption capacity of HDTMA-bentonite towards OG was higher. Such performance by HDTMAbentonite resulted from the increased affinity of OG due to the increased hydrophobicity of the bentonite particles. In a different study, Salam, Kosa (49) modified montmorillonite nanoclay using octadecylamine. The octadecylamine modified montmorillonite nanoclay (ODA) had a BET specific surface area of $16.38 \mathrm{~m}^{2} / \mathrm{g}$. Adsorption study revealed that the ODA could remove OG within few minutes with an adsorption capacity of $39.4 \mathrm{mg} / \mathrm{g}$.

\subsection{Metal oxides}

Various oxides with metal ions have also been used as adsorbents for the removal of various pollutants, including OG. For instance, Mondal, Singh (50) made use of hematite $(\alpha-$ $\mathrm{Fe}_{2} \mathrm{O}_{3}$ ) as adsorbent for the removal of OG. The adsorption of OG using hematite was found to decrease with increase in $\mathrm{pH}$, temperature and initial concentration. The adsorption process was spontaneous and exothermic. In a different study, Gusain, Dubey (51) made use of nano zirconia $\left(\mathrm{ZrO}_{2}\right)$ as adsorbent for the removal of OG. Higher percentage removal was recorded at $\mathrm{pH} \mathrm{2}$, and the adsorption process was exothermic. Nassar, Mohamed (16) reported the use of $\alpha-\mathrm{Fe}_{2} \mathrm{O}_{3}, \mathrm{CoFe}_{2} \mathrm{O}_{4}$ and $\mathrm{Co}_{3} \mathrm{O}_{4}$ as adsorbents for the removal of OG. Due to electrostatic attraction at low $\mathrm{pH}$, maximum adsorption using $\alpha-\mathrm{Fe}_{2} \mathrm{O}_{3}$, $\mathrm{CoFe}_{2} \mathrm{O}_{4}$ and $\mathrm{Co}_{3} \mathrm{O}_{4}$ was recorded at $\mathrm{pH} \mathrm{3,} 2$ and 2. The adsorption process was endothermic and spontaneous. Magnesium oxide $(\mathrm{MgO})$ nanostructures have been synthesized by Nassar, Mohamed (52) via hybrid sol-gel combustion method using urea, oxalic acid and citric acid as fuels. Maximum removal was recorded at $\mathrm{pH} 4$, and the $\mathrm{MgO}$ synthesized using oxalic acid as fuel had the highest adsorption capacity. The adsorption process was spontaneous and exothermic.

\subsection{Layered double hydroxides-based adsorbents}

Layered double hydroxides (LDHs) are clay minerals containing layers of positively charged metal hydroxides and multivalent anions for neutrality (53). They have a unique structure, high chemical and thermal stability and could be synthesized easily (54). Furthermore, due to their low cost, high surface area, non-toxicity, highly tunable interior architecture and exchangeable anionic features, studies have reported the use of LDHs as adsorbents in wastewater remediation (55). For instance, Abdelkader, Bentouami (6) have reported the use of calcined and uncalcined $\mathrm{Mg}-\mathrm{Fe}-\mathrm{CO}_{3}$ as adsorbent for the removal of OG dye. The amount adsorbed using calcined $\mathrm{Mg}$ $\mathrm{Fe}-\mathrm{CO}_{3}$ was much higher than the amount adsorbed using uncalcined $\mathrm{Mg}-\mathrm{Fe}-\mathrm{CO}_{3}$. Such effect was due to the difference in adsorption process which might have occurred via ion exchange mechanism in the case of uncalcined $\mathrm{Mg}-\mathrm{Fe}-\mathrm{CO}_{3}$ and via both surface and ion exchange phenomena in the case of calcined $\mathrm{Mg}-\mathrm{Fe}-\mathrm{CO}_{3}$.

\subsection{Polymer-based adsorbents}

Polymers are materials consisting of many repeating units and have also been used as adsorbents for the removal of various pollutants including OG dye. For instance, Zhang, Wang (56) employed the use of pristine and copper modified poly(m-phenylenediamine) (PmPD) as adsorbents for the removal of OG dye. Compared to pristine PmPD, the PmPD synthesized with $\mathrm{Cu}^{2+}$ was found to have a high surface area. Such a high surface area resulted in increased performance by the modified PmPD during adsorption. The equilibrium time for the adsorption was $180 \mathrm{~min}$, and the isotherm data fitted well with the Langmuir model, an indication of monolayer adsorption. The use of surfactants, octadecyl trimethyl ammonium chloride (OTAC), dioctadecyl dimethyl ammonium chloride (DDAC), dodecyl trimethyl ammonium chloride (DTAC) and benzyl hexadecyl dimethyl ammonium chloride (BHDAC) to enhance the adsorption capacity of chitosan towards OG dye has been reported by Zhang, Cheng (57). The adsorption efficiency for OG using the chitosan/surfactant followed the order: DTAC > DDAC > OTAC > BHDAC. The maximum removal of OG using chitosan/DTAC was recorded at $\mathrm{pH} 3.0$, and the removal was found to decrease with an increase in $\mathrm{pH}$ from $3.0-10.0$. However, equilibrium was achieved within $240 \mathrm{~min}$, and the adsorption process was exothermic. In a different study, magnetic chitosan nanoparticles $(\mathrm{MCN})$ were modified using ethylenediamine to form EMCN. The adsorption capacity of EMCN towards OG was higher than that of MCN due to the higher concentration of active sites in EMCN. Moreover, the EMCN could be separated easily using a magnet, and the adsorption process towards OG dye was spontaneous and exothermic. Another form of modification involves grafting chitosan onto monomers. For instance, grafted crosslinked chitosan using N-vinyl-2-pyrrolidone as a monomer. Although the adsorption capacity of grafted (cts(x)-g-PNVP) towards OG dye was higher than that of chitosan, however, the adsorption capacities of both adsorbents were high at low $\mathrm{pH}$ due to a decrease in the number of protonated amines on the adsorbents with an increase in $\mathrm{pH}$. The low efficiency recorded using the ungrafted chitosan was due to its high swelling ability, which makes it very brittle. Furthermore, Konaganti, Kota (58) also synthesized chitosan-based copolymers by grafting chitosan 
onto a series of poly(alkyl methacrylate)s to produce ChgPMMA (chitosan grafted poly(methyl methacrylate)), ChgPEMA (chitosan grafted poly(ethyl methacrylate)), ChgPBMA (chitosan grafted poly(butyl methacrylate)), ChgPHMA (chitosan grafted polyhexyl methacrylate)). Both ungrafted chitosan and the grafted copolymers were subsequently used as adsorbents for the removal of OG dye. The grafted polymers were found to exhibit higher adsorption capacity compared to that of ungrafted chitosan, and adsorption capacity follows the order ChgPMMA > ChgPEMA > ChgPBMA > ChgPHMA > ungrafted chitosan. Wu, Wang (59) also synthesized chitosan/diatomite (CS/DM) membranes by phase inversion technique. The diatomite was introduced to improve the mechanical and adsorption properties of CS. The adsorption capacity of the CS/DM membrane was found to be dependent on initial OG concentration, $\mathrm{pH}$ value, adsorbent dosage and contact time. The efficiency for the removal of $\mathrm{OG}$ using CS/DM membrane reached $94.0 \%$.

Dulman, Cucu-Man (7) made use of crosslinked acrylic copolymer functionalized with triethylenetetramine as adsorbent for the removal of OG. The electrostatic attraction between the dye anions and the protonated amine groups of the adsorbent plays a vital role for the system, and the adsorption process was spontaneous and endothermic. In a different study, Sandić, Nastasović (60) made use of macroporous poly(glycidyl methacrylate-coethylene glycol dimethacrylate) (PGME) functionalized with diethylene triamine (PGME-deta) for the adsorption of OG. Adsorption of OG using PGME-deta reached $96 \%$ at $\mathrm{pH} 2$ but decreased to $5 \%$ at $\mathrm{pH} 11$. The dye sorption was due to the electrostatic attraction between positively charged amine groups on the PGME-deta surface and the negatively charged sulfonate groups on OG. Also, coordination supramolecular polymer $\left[\mathrm{Cu}(\text { bipy })\left(\mathrm{SO}_{4}\right)\right]_{n}$, has been used as adsorbent by Xiao, Xiong (61) for the removal of a high concentration of OG. The adsorption of OG using $\left[\mathrm{Cu}(\text { bipy })\left(\mathrm{SO}_{4}\right)\right]_{n}$ occurred via ion exchange, and the material displayed high adsorption capacity for the removal of OG.

\subsection{Other materials}

Several other materials have also been used as adsorbents for the removal of OG dye. For instance, Bhatnagar, Minocha (29) made use of paper mill sludge (a waste material generated from paper industries) as adsorbent for the removal of OG dye. Maximum percentage removal $(75-80 \%)$ was recorded at $\mathrm{pHs}$ $2-4$, and the efficiency decreases as the $\mathrm{pH}$ increases. Such an effect was attributed to the electrostatic attraction at low $\mathrm{pH}$ and electrostatic repulsion at high $\mathrm{pH}$. Another waste material from the sugar industry, bagasse fly ash (BFA) has been used by Mall, Srivastava (62) as adsorbent for the removal of OG dye from aqueous solution. BFA was found to have a high surface area, pore size and pore volume. The removal of OG using BFA was maximum at acidic $\mathrm{pH}(\mathrm{pH} 3-4)$, and the kinetic study revealed that the adsorption of OG onto BFA is a gradual process.

Singh, Banerjee (27) reported the use of raw and modified (using sulphuric acid and sodium bicarbonate) sawdust as adsorbents for the removal of OG dye from aqueous solution. However, both adsorbents had an appreciable adsorption capacity towards OG dye, in a process that was spontaneous and exothermic. In a different study, Banerjee, Chattopadhyaya
(18) modified sawdust using perchloric acid for use as adsorbent for the removal of $\mathrm{OG}$ dye. The adsorption reaches equilibrium in $90 \mathrm{~min}$, and the removal percentage decreases from 78.3 to $36.3 \%$ with increase in temperature from 30 to 50 ${ }^{\circ} \mathrm{C}$, an indication that the process is exothermic. Arzani, Ashtiani (14) synthesized a carbon mesoporous material (CMK-3) using SBA-15 silica mesoporous as hard template. The CMK-3 was considered as a potential candidate for the removal of $\mathrm{OG}$ dye due to its well-ordered mesoporous structure, high surface area, large pore volume and narrow pore size distribution. The CMK-3 was found to have a surface area of $918 \mathrm{~m}^{2} / \mathrm{g}$ and average pore diameter of $3.64 \mathrm{~nm}$. Due to the protonation of CMK-3 at lower solution $\mathrm{pH}$, its adsorption capacity towards OG was much higher at low $\mathrm{pH}$. The use of magnetic biochar derived from the empty fruit bunch (EFB) as adsorbent for the removal of OG dye has been reported by Mubarak, Fo (63). The material was reported to possess an excellent adsorption capacity for the removal of OG dye, and optimized performance was recorded at $\mathrm{pH} 2$ and contact time of $120 \mathrm{~min}$. Mesoporous molecular sieves (SBA-3) have also been used by Anbia, Hariri (64) for the removal of OG. In their study, SBA-3 was calcined at $550{ }^{\circ} \mathrm{C}$ to remove the surfactant template and produce C-SBA-3. However, it was observed that the adsorption capability of SBA-3 towards OG dye was higher than that of C-SBA-3. Such effect was attributed to the polar groups present on the surface of SBA-3 created by the surfactant template, which imparted significant adsorption capacity towards anions to SBA-3.

The use of monoamine modified magnetic silica (MAMMS) and monoamine modified magnetite-free silica (MAMPS) as adsorbents for the removal of OG dye from aqueous solution has been reported by Atia, Donia (65). The maximum performance using both silica samples was recorded at $\mathrm{pH}$ 3. However, MAMMS showed higher adsorption capacity towards OG compared to MAMPS. Such performance by MAMMS was attributed to the thin film of silica that was formed on the magnetite particles, which increased the number of exposed active sites available for interaction with OG. In a different study, Zheng, Zheng (66) made use of quaternary ammonium group-rich magnetic nanoparticles (MNPs), Fe3O4@SiO2-MPS-g-DAC (FSMD) synthesized via graft polymerization, as adsorbent for the removal of OG. FMSD had a shorter adsorption equilibrium time (20 $\mathrm{min})$ and the main adsorption mechanism was electrostatic interaction. The adsorption capacity of FSMD MNPs remained high at $\mathrm{pH} 2.0$ to 7.0, an indication that FMSD MNPs had good affinity to OG at a wide $\mathrm{pH}$ range. The adsorption process was spontaneous and endothermic. A study aimed at investigating the adsorption potential of anion exchangers with different functional groups (Amberlite IRA-900, Amberlite IRA-910, Amberlyst A-21) towards removing OG dye has been conducted by Greluk and Hubicki (67). The adsorption capacities of the anion exchangers towards OG was related to their basicity, as strongly basic anion exchanger of type 1 (Amberlite IRA-900) $>$ strongly basic anion exchanger of type 2 (Amberlite IRA$910)>$ weakly basic anion exchanger (Amberlyst A-21). The kinetic measurement showed that the adsorption process was uniform and rapid.

Table 2: List of adsorbents used for adsorption studies of OG

\begin{tabular}{|l|l|l|l|l|l|}
\hline Adsorbent & Experimental conditions & $\begin{array}{l}\text { Capability } \\
\text { (mg/g) }\end{array}$ & $\begin{array}{l}\text { Isotherm } \\
\text { model }\end{array}$ & $\begin{array}{l}\text { Kinetic } \\
\text { model }\end{array}$ & Ref. \\
\hline Bagasse fly ash (BFA) & $\begin{array}{l}\text { Dosage: } 0.1 \mathrm{~g}, \text { volume: } 50 \mathrm{~mL}, \\
\text { concentration: } 10 \mathrm{mg} / \mathrm{L}, \text { shaking } \\
\text { speed: } 150 \mathrm{rpm}, \text { temperature: } 30{ }^{\circ} \mathrm{C}\end{array}$ & 13.79 & $\mathrm{~F}$ & PSO & $(62)$ \\
\hline
\end{tabular}




\begin{tabular}{|c|c|c|c|c|c|}
\hline Adsorbent & Experimental conditions & $\begin{array}{l}\text { Capability } \\
(\mathrm{mg} / \mathrm{g})\end{array}$ & $\begin{array}{l}\text { Isotherm } \\
\text { model }\end{array}$ & $\begin{array}{l}\text { Kinetic } \\
\text { model }\end{array}$ & Ref. \\
\hline Paper mill sludge & $\begin{array}{l}\text { Dosage: } 0.10 \mathrm{~g} \text {, volume: } 10 \mathrm{~mL} \text {, } \\
\text { temperature: } 25^{\circ} \mathrm{C} \text {, concentration: } \\
5.5 \times 10^{-4} \mathrm{M}\end{array}$ & 62.3 & $\mathrm{~L}$ & PSO & (29) \\
\hline Tobacco leaves (TL) & $\begin{array}{l}\text { Dosage: } 0.25 \mathrm{~g}, \text { volume: } 25 \mathrm{~mL} \\
\text { pH: } 10, \text { shaking speed: } 110 \mathrm{rpm}\end{array}$ & 41.66 & $\mathrm{~F}$ & PSO & (39) \\
\hline $\begin{array}{l}\text { Monoamine modified magnetic } \\
\text { silica (MAMMS) }\end{array}$ & $\begin{array}{l}\text { Dosage: } 0.1 \mathrm{~g} \text {, volume } 100 \mathrm{~cm}^{3} \text {, } \\
\text { temperature: } 298 \mathrm{~K} \text {, concentration: } \\
48 \mathrm{mg} \mathrm{dm}^{-3} \text {, shaking speed: } 400 \\
\mathrm{rpm}\end{array}$ & 61.33 & $\mathrm{~L}$ & PSO & (65) \\
\hline $\begin{array}{l}\text { Monoamine modified magnetite- } \\
\text { free silica (MAMPS) }\end{array}$ & $\begin{array}{l}\text { Dosage: } 0.1 \mathrm{~g} \text {, volume } 100 \mathrm{~cm}^{3} \text {, } \\
\text { temperature: } 298 \mathrm{~K} \text {, concentration: } \\
48 \mathrm{mg} \mathrm{dm}^{-3} \text {, shaking speed: } 400 \\
\mathrm{rpm}\end{array}$ & 48.98 & $\mathrm{~L}$ & PSO & (65) \\
\hline Ungrafted chitosan & $\begin{array}{l}\text { Dosage: } 150 \mathrm{mg} \text {, volume: } 50 \mathrm{~mL} \text {, } \\
\text { concentration: } 300 \mathrm{ppm}, \mathrm{pH}: 7\end{array}$ & 34 & $\mathrm{~L}$ & PSO & (58) \\
\hline $\begin{array}{l}\text { Chitosan grafted poly(methyl } \\
\text { methacrylate) }\end{array}$ & $\begin{array}{l}\text { Dosage: } 150 \mathrm{mg} \text {, volume: } 50 \mathrm{~mL} \text {, } \\
\text { concentration: } 300 \mathrm{ppm}, \mathrm{pH}: 7\end{array}$ & 87.2 & $\mathrm{~L}$ & PSO & (58) \\
\hline $\begin{array}{l}\text { Chitosan grafted poly(ethyl } \\
\text { methacrylate) }\end{array}$ & $\begin{array}{l}\text { Dosage: } 150 \mathrm{mg} \text {, volume: } 50 \mathrm{~mL} \text {, } \\
\text { concentration: } 300 \mathrm{ppm}, \mathrm{pH}: 7\end{array}$ & 86.7 & $\mathrm{~L}$ & PSO & (58) \\
\hline $\begin{array}{l}\text { Chitosan grafted poly(butyl } \\
\text { methacrylate) }\end{array}$ & $\begin{array}{l}\text { Dosage: } 150 \mathrm{mg} \text {, volume: } 50 \mathrm{~mL} \text {, } \\
\text { concentration: } 300 \mathrm{ppm}, \mathrm{pH}: 7\end{array}$ & 84 & $\mathrm{~L}$ & PSO & (58) \\
\hline $\begin{array}{l}\text { Chitosan grafted poly(hexyl } \\
\text { methacrylate) }\end{array}$ & $\begin{array}{l}\text { Dosage: } 150 \mathrm{mg} \text {, volume: } 50 \mathrm{~mL} \text {, } \\
\text { concentration: } 300 \mathrm{ppm}, \mathrm{pH}: 7\end{array}$ & 80.6 & $\mathrm{~L}$ & PSO & (58) \\
\hline $\begin{array}{l}\text { Mesoporous molecular sieves } \\
\text { (SBA-3) }\end{array}$ & $\begin{array}{l}\text { Dosage: } 50 \mathrm{mg} \text {, volume: } 250 \mathrm{~mL} \text {, } \\
\text { pH: } 7 \text {, temperature: } 24{ }^{\circ} \mathrm{C} \text {, initial } \\
\text { concentration: } 30 \mathrm{mg} / \mathrm{L}\end{array}$ & 135.1 & $\mathrm{~F}$ & PSO & (64) \\
\hline Na-bentonite & $\begin{array}{l}\text { Dosage: } 0.01 \mathrm{~g} \text {, volume: } 0.050 \\
\mathrm{dm} 3 \text {, conc: } 50 \mathrm{mg} \mathrm{dm}-3 \text {, } \\
\text { temperature: } 25^{\circ} \mathrm{C}\end{array}$ & 0.84 & - & PSO & (48) \\
\hline $\begin{array}{l}\text { Hexadecyl } \\
\text { trimethylammoniumbromide } \\
\text { (HDTMA-bromide) }\end{array}$ & $\begin{array}{l}\text { Dosage: } 0.01 \mathrm{~g} \text {, volume: } 0.050 \\
\mathrm{dm}^{3} \text {, conc: } 50 \mathrm{mg} \mathrm{dm}^{-3} \text {, } \\
\text { temperature: } 25^{\circ} \mathrm{C}\end{array}$ & 101.42 & - & PSO & (48) \\
\hline Hematite $\left(\alpha-\mathrm{Fe}_{2} \mathrm{O}_{3}\right)$ & $\begin{array}{l}\text { Dosage: } 1 \mathrm{~g} \text {, volume: } 50 \mathrm{~mL}, \\
\text { concentration: } 25 \mathrm{mg} / \mathrm{L} \text {, } \\
\text { temperature: } 303 \mathrm{~K}\end{array}$ & 0.63 & $\mathrm{~F}$ & - & (50) \\
\hline $\begin{array}{l}\text { Macroporous poly(glycidyl } \\
\text { methacrylate-coethylene glycol } \\
\text { dimethacrylate) (PGME) } \\
\text { functionalized with diethylene } \\
\text { triamine (PGME-deta) }\end{array}$ & $\begin{array}{l}\text { Dosage: } 25 \mathrm{mg} \text {, volume: } 50 \mathrm{~cm}^{3} \text {, } \\
\text { temperature: } 25^{\circ} \mathrm{C}\end{array}$ & 123.9 & $\mathrm{~L}$ & PSO & (60) \\
\hline Thespesia populnea pods & $\begin{array}{l}\text { Dosage: } 0.2 \mathrm{~g} / 25 \mathrm{~mL} \text {, agitation: } \\
200 \mathrm{rpm} \text {, contact time: } 300 \mathrm{~min} \text {, } \\
\text { dye concentration: } 10 \mathrm{mg} / \mathrm{L} \text {. }\end{array}$ & 9.129 & $\mathrm{~F}$ & PSO & (43) \\
\hline Uncalcined $\mathrm{Mg}-\mathrm{Fe}-\mathrm{CO}_{3}$ & $\begin{array}{l}\text { Dosage: } 1 \mathrm{~g} / \mathrm{L}, \text { concentration: } 200 \\
\mathrm{mg} / \mathrm{L} \text {. }\end{array}$ & 76.4 & $\mathrm{~L}$ & PSO & (6) \\
\hline Calcined $\mathrm{Mg}-\mathrm{Fe}-\mathrm{CO}_{3}$ & $\begin{array}{l}\text { Dosage: } 1 \mathrm{~g} / \mathrm{L}, \text { concentration: } 200 \\
\mathrm{mg} / \mathrm{L} \text {. }\end{array}$ & 378.8 & $\mathrm{~L}$ & PSO & (6) \\
\hline $\begin{array}{l}\text { Ethylenediamine-modified } \\
\text { magnetic chitosan particles } \\
\text { (EMCN) }\end{array}$ & $\begin{array}{l}\text { Dosage: } 1 \mathrm{~g} / \mathrm{L} \text {, concentration: } 5 \times \\
10^{-3} \mathrm{mmol} / \mathrm{L} \text {, shaking rate: } 200 \\
\mathrm{rpm} \text {, temperature: } 298 \mathrm{~K} .\end{array}$ & 1017 & $\mathrm{~L}$ & - & (68) \\
\hline Raw saw dust & $\begin{array}{l}\text { Dosage: } 1 \mathrm{~g} / \mathrm{L} \text {, volume: } 50 \mathrm{~mL}, \mathrm{pH} \text { : } \\
\text { 2, concentration: } 2.5 \mathrm{mg} / \mathrm{L} \text {, } \\
\text { temperature: } 308 \mathrm{~K}\end{array}$ & 0.24 & $\mathrm{~F}$ & - & (27) \\
\hline Modified saw dust & $\begin{array}{l}\text { Dosage: } 1 \mathrm{~g} / \mathrm{L} \text {, volume: } 50 \mathrm{~mL}, \mathrm{pH}: \\
\text { 2, concentration: } 2.5 \mathrm{mg} / \mathrm{L} \text {, } \\
\text { temperature: } 308 \mathrm{~K}\end{array}$ & 0.40 & $\mathrm{~F}$ & - & (27) \\
\hline poly(m-phenylenediamine) & $\begin{array}{l}\text { Dosage: } 25 \mathrm{mg} \text {, concentration: } 240 \\
\text { mg/L, volume: } 50 \mathrm{~mL} \text {, reaction } \\
\text { temperature: } 30^{\circ} \mathrm{C} \text {, reaction time: } \\
180 \text { min. }\end{array}$ & 163.9 & $\mathrm{~L}$ & PSO & (56) \\
\hline $\mathrm{Cu}^{2+}-$ poly(m-phenylenediamine $)$ & $\begin{array}{l}\text { Dosage: } 25 \mathrm{mg} \text {, concentration: } 240 \\
\mathrm{mg} / \mathrm{L} \text {, volume: } 50 \mathrm{~mL} \text {, reaction } \\
\text { temperature: } 30^{\circ} \mathrm{C} \text {, reaction time: } \\
180 \text { min. }\end{array}$ & 387.6 & $\mathrm{~L}$ & PSO & (56) \\
\hline
\end{tabular}




\begin{tabular}{|c|c|c|c|c|c|}
\hline Adsorbent & Experimental conditions & $\begin{array}{l}\text { Capability } \\
(\mathrm{mg} / \mathrm{g})\end{array}$ & $\begin{array}{l}\text { Isotherm } \\
\text { model }\end{array}$ & $\begin{array}{l}\text { Kinetic } \\
\text { model }\end{array}$ & Ref. \\
\hline $\begin{array}{l}\text { Carbon mesoporous material } \\
\text { (CMK-3) }\end{array}$ & $\begin{array}{l}\text { Dosage: } 50 \mathrm{mg} \text {, concentration: } \\
1000 \mathrm{mg} / \mathrm{L}, \text { volume: } 25 \mathrm{~mL}\end{array}$ & 189 & $\mathrm{~L}$ & PSO & (14) \\
\hline Amberlite IRA-900 & $\begin{array}{l}\text { Dosage: } 0.2 \mathrm{~g} \text {, volume } 20 \mathrm{~mL} \text {, } \\
\text { temperature: } 298 \mathrm{~K} \text {, shaking speed: } \\
180 \mathrm{rpm}\end{array}$ & 1012.62 & $\mathrm{~L}$ & PSO & (67) \\
\hline Amberlite IRA-910 & $\begin{array}{l}\text { Dosage: } 0.2 \text { g, volume } 20 \mathrm{~mL} \text {, } \\
\text { temperature: } 298 \mathrm{~K} \text {, shaking speed: } \\
180 \mathrm{rpm}\end{array}$ & 923.48 & $\mathrm{~L}$ & PSO & (67) \\
\hline Amberlyst A-21 & $\begin{array}{l}\text { Dosage: } 0.2 \mathrm{~g} \text {, volume } 20 \mathrm{~mL} \text {, } \\
\text { temperature: } 298 \mathrm{~K} \text {, shaking speed: } \\
180 \mathrm{rpm}\end{array}$ & 139.12 & $\mathrm{~L}$ & PSO & (67) \\
\hline $\begin{array}{l}\text { Magnetic graphene oxide } \\
\text { nanocomposite }\end{array}$ & $\begin{array}{l}\text { Dosage: } 1 \mathrm{~g} / \mathrm{L}, \mathrm{pH}: 6 \text {, temperature: } \\
25^{\circ} \mathrm{C} \text {, concentration: } 60 \mathrm{mg} / \mathrm{L}\end{array}$ & 20.85 & $\mathrm{~L}$ & PSO & (69) \\
\hline $\begin{array}{l}\text { Pyracantha coccinea modified with } \\
\text { hegzadecylethyldimethylammonium } \\
\text { bromide (HDEDMABr) }\end{array}$ & $\begin{array}{l}\text { Dosage: } 2.4 \mathrm{~g} / \mathrm{L} \text {, volume: } 25 \mathrm{~mL} \text {, } \\
\text { pH: } 4 \text { concentration: } 100 \mathrm{mg} / \mathrm{L}\end{array}$ & 90.16 & $\mathrm{~L}$ & PSO & (34) \\
\hline Activated carbon & $\begin{array}{l}\text { Dosage: } 20 \mathrm{mg} \text {, volume: } 100 \mathrm{~mL} \text {, } \\
\text { concentration: } 400 \mathrm{mg} / \mathrm{L}, \mathrm{pH}: 3 \text {, } \\
\text { temperature: } 293.15 \mathrm{~K} \text {, shaking } \\
\text { speed: } 200 \mathrm{rpm}\end{array}$ & 555.34 & - & - & (57) \\
\hline Bentonite & $\begin{array}{l}\text { Dosage: } 20 \mathrm{mg} \text {, volume: } 100 \mathrm{~mL} \text {, } \\
\text { concentration: } 400 \mathrm{mg} / \mathrm{L}, \mathrm{pH}: 3 \text {, } \\
\text { temperature: } 293.15 \mathrm{~K} \text {, shaking } \\
\text { speed: } 200 \mathrm{rpm}\end{array}$ & 210.06 & - & - & (57) \\
\hline Activated clay & $\begin{array}{l}\text { Dosage: } 20 \mathrm{mg} \text {, volume: } 100 \mathrm{~mL} \text {, } \\
\text { concentration: } 400 \mathrm{mg} / \mathrm{L}, \mathrm{pH}: 3 \text {, } \\
\text { temperature: } 293.15 \mathrm{~K} \text {, shaking } \\
\text { speed: } 200 \mathrm{rpm}\end{array}$ & 128.61 & - & - & (57) \\
\hline Spirulina powder & $\begin{array}{l}\text { Dosage: } 20 \mathrm{mg}, \text { volume: } 100 \mathrm{~mL} \text {, } \\
\text { concentration: } 400 \mathrm{mg} / \mathrm{L}, \mathrm{pH}: 3 \text {, } \\
\text { temperature: } 293.15 \mathrm{~K} \text {, shaking } \\
\text { speed: } 200 \mathrm{rpm}\end{array}$ & 344.76 & - & - & (57) \\
\hline Chitosan & $\begin{array}{l}\text { Dosage: } 20 \mathrm{mg} \text {, volume: } 100 \mathrm{~mL} \text {, } \\
\text { concentration: } 400 \mathrm{mg} / \mathrm{L}, \mathrm{pH}: 3 \text {, } \\
\text { temperature: } 293.15 \mathrm{~K} \text {, shaking } \\
\text { speed: } 200 \mathrm{rpm}\end{array}$ & 1270.71 & - & - & (57) \\
\hline Chitosan/DTAC & $\begin{array}{l}\text { Dosage: } 20 \mathrm{mg} \text {, volume: } 100 \mathrm{~mL} \text {, } \\
\text { DTAC: } 34.10 \mu \mathrm{M} \text {, concentration: } \\
400 \mathrm{mg} / \mathrm{L} \text {, pH: } 3 \text {, temperature: } \\
293.15 \mathrm{~K} \text {, shaking speed: } 200 \mathrm{rpm}\end{array}$ & 1452.07 & $\mathrm{~L}$ & PSO & (57) \\
\hline Cerium dioxide nanoparticles & $\begin{array}{l}\text { Dosage: } 2 \mathrm{~g} / \mathrm{L}, \mathrm{pH}: 2 \\
\text { concentration: } 15 \mathrm{mg} / \mathrm{L}\end{array}$ & 33.33 & $\mathrm{~L}$ & - & (70) \\
\hline$\left[\mathrm{Cu}(\text { bipy })\left(\mathrm{SO}_{4}\right)\right]_{n}$ & $\begin{array}{l}\text { Dosage: } 20 \mathrm{mg} / 40 \mathrm{~mL} \\
\text { concentration: } 500 \mathrm{mg} / \mathrm{L}\end{array}$ & 1333 & $\mathrm{~L}$ & PSO & (61) \\
\hline Magnetic biochar & $\begin{array}{l}\text { Dosage: } 1.00 \mathrm{~g}, \mathrm{pH}: 2 \text {, agitation } \\
\text { speed: } 125 \mathrm{rpm} \text {, contact time: } 120 \\
\text { min }\end{array}$ & 32.36 & $\mathrm{~L}$ & PSO & (63) \\
\hline $\begin{array}{l}\text { Sawdust modified with perchloric } \\
\text { acid }\end{array}$ & $\begin{array}{l}\text { Dosage: } 20 \mathrm{~g} / \mathrm{L}, \text { volume: } 50 \mathrm{~mL} \text {, } \\
\text { pH: } 2 \text {, concentration: } 50 \mathrm{mg} / \mathrm{L} \text {, } \\
\text { shaking speed: } 100 \mathrm{rpm}\end{array}$ & 5.48 & $\mathrm{~L}$ & PFO & (18) \\
\hline Modified wheat husk & $\begin{array}{l}\text { Dosage: } 5 \mathrm{~g} / \mathrm{L} \text {, volume: } 100 \mathrm{~mL} \text {, } \\
\text { pH: } 2 \text {, agitation speed: } 200 \mathrm{rpm}\end{array}$ & 31.25 & $\mathrm{~F}$ & PSO & (37) \\
\hline $\begin{array}{l}\text { Crosslinked acrylic copolymer } \\
\text { functionalized with } \\
\text { triethylenetetramine }\end{array}$ & $\begin{array}{l}\text { Dosage: } 0.25 \mathrm{~g} \text {, volume: } 100 \mathrm{~mL} \text {, } \\
\text { pH: } 2 \text {, temperature: } 323 \mathrm{~K} .\end{array}$ & 1218 & NLL & PSO & (7) \\
\hline $\begin{array}{l}\text { Chitosan/diatomite (CS/DM) } \\
\text { membrane }\end{array}$ & $\begin{array}{l}\text { Dosage: } 8 \mathrm{mg} \text {, concentration: } 200 \\
\mathrm{mg} / \mathrm{L}, \mathrm{pH}: 3\end{array}$ & 588 & $\mathrm{RP}$ & PSO & (59) \\
\hline $\mathrm{Fe}_{3} \mathrm{O}_{4} / \mathrm{MIL}-101(\mathrm{Cr})$ & $\begin{array}{l}\text { Dosage: } 30 \mathrm{mg} / 50 \mathrm{~mL}, \mathrm{pH}: 3, \\
\text { concentration: } 50 \mathrm{mg} / \mathrm{L} \text {, } \\
\text { temperature: } 298 \mathrm{~K} \text {. }\end{array}$ & 200 & $\mathrm{~L}$ & PSO & (71) \\
\hline Nano zirconia $\left(\mathrm{ZrO}_{2}\right)$ & $\begin{array}{l}\text { Dosage: } 2 \mathrm{~g} / \mathrm{L} \text {, concentration: } 50 \\
\text { ppm, volume: } 50 \mathrm{~mL} \text {, steering } \\
\text { speed: } 90 \mathrm{rpm} \text {, temperature: } 30^{\circ} \mathrm{C}\end{array}$ & - & - & - & (51) \\
\hline
\end{tabular}




\begin{tabular}{|c|c|c|c|c|c|}
\hline Adsorbent & Experimental conditions & $\begin{array}{l}\text { Capability } \\
(\mathrm{mg} / \mathrm{g})\end{array}$ & $\begin{array}{l}\text { Isotherm } \\
\text { model }\end{array}$ & $\begin{array}{l}\text { Kinetic } \\
\text { model }\end{array}$ & Ref. \\
\hline $\mathrm{ZnO}-\mathrm{AC}$ & $\begin{array}{l}\text { Dosage: } 0.02 \mathrm{~g} / 50 \mathrm{~mL}, \mathrm{pH}: 2, \\
\text { concentration: } 50 \mathrm{mg} / \mathrm{L} \text {, } \\
\text { temperature: } 343 \mathrm{~K} .\end{array}$ & 153.8 & $\mathrm{~L}$ & PSO & (26) \\
\hline$\alpha-\mathrm{Fe}_{2} \mathrm{O}_{3}$ & $\begin{array}{l}\text { Dosage: } 0.05 \mathrm{~g} \text {, volume: } 50 \mathrm{~mL} \text {, } \\
\text { concentration: } 50 \mathrm{mg} / \mathrm{L}, \mathrm{pH}: 3 \text {, } \\
\text { steering speed: } 400 \mathrm{rpm}, \\
\text { temperature: } 25^{\circ} \mathrm{C}\end{array}$ & 62.0 & $\mathrm{~L}$ & PSO & (16) \\
\hline $\mathrm{CoFe}_{2} \mathrm{O}_{4}$ & $\begin{array}{l}\text { Dosage: } 0.05 \mathrm{~g} \text {, volume: } 50 \mathrm{~mL} \text {, } \\
\text { concentration: } 50 \mathrm{mg} / \mathrm{L}, \mathrm{pH}: 2 \text {, } \\
\text { steering speed: } 400 \mathrm{rpm}, \\
\text { temperature: } 25^{\circ} \mathrm{C}\end{array}$ & 52.3 & $\mathrm{~L}$ & PSO & (16) \\
\hline $\mathrm{Co}_{3} \mathrm{O}_{4}$ & $\begin{array}{l}\text { Dosage: } 0.05 \mathrm{~g}, \text { volume: } 50 \mathrm{~mL} \text {, } \\
\text { concentration: } 50 \mathrm{mg} / \mathrm{L}, \mathrm{pH}: 2, \\
\text { steering speed: } 400 \mathrm{rpm}, \\
\text { temperature: } 25^{\circ} \mathrm{C}\end{array}$ & 33.3 & $\mathrm{~L}$ & PSO & (16) \\
\hline $\begin{array}{l}\text { Matured tea leaf activated carbon } \\
\text { (MTLAC) }\end{array}$ & $\begin{array}{l}\text { Dosage: } 1 \mathrm{~g} / \mathrm{L}, \text { concentration: } 200 \\
\mathrm{mg} / \mathrm{L} \text {, temperature: } 303 \mathrm{~K} \text {. }\end{array}$ & 318.5 & $\mathrm{~L}$ & PSO & (45) \\
\hline $\begin{array}{l}\text { Sulfonic acid functionalized } \\
\text { MTLAC (MTLAC-SA) }\end{array}$ & $\begin{array}{l}\text { Dosage: } 1 \mathrm{~g} / \mathrm{L} \text {, concentration: } 200 \\
\mathrm{mg} / \mathrm{L} \text {, temperature: } 303 \mathrm{~K}\end{array}$ & 105.7 & $\mathrm{~L}$ & PSO & $(45)$ \\
\hline $\begin{array}{l}\text { Octadecylamine modified } \\
\text { montmorillonite nanoclay (ODA) }\end{array}$ & $\begin{array}{l}\text { Dosage: } 20 \mathrm{mg} \text {, volume: } 20 \mathrm{~mL} \text {, } \\
\mathrm{pH}: 8 \text {, concentration: } 50 \mathrm{mg} / \mathrm{L} \text {, } \\
\text { temperature: } 296 \mathrm{~K}\end{array}$ & 39.4 & - & PSO & (49) \\
\hline $\begin{array}{l}\text { Magnesium oxide }(\mathrm{MgO}) \\
\text { synthesized using urea as fuel and } \\
\text { calcined at } 550^{\circ} \mathrm{C}\end{array}$ & $\begin{array}{l}\text { Dosage: } 0.05 \mathrm{mg} \text {, volume: } 25 \mathrm{~mL} \text {, } \\
\text { pH: } 4 \text {, temperature: } 25^{\circ} \mathrm{C}\end{array}$ & 19.3 & $\mathrm{~L}$ & PSO & $(52)$ \\
\hline $\begin{array}{l}\text { Magnesium oxide }(\mathrm{MgO}) \\
\text { synthesized using urea as fuel and } \\
\text { calcined at } 800^{\circ} \mathrm{C}\end{array}$ & $\begin{array}{l}\text { Dosage: } 0.05 \mathrm{mg} \text {, volume: } 25 \mathrm{~mL} \text {, } \\
\mathrm{pH}: 4 \text {, temperature: } 25^{\circ} \mathrm{C}\end{array}$ & 11.8 & $\mathrm{~L}$ & PSO & $(52)$ \\
\hline $\begin{array}{l}\text { Magnesium oxide }(\mathrm{MgO}) \\
\text { synthesized using oxalic acid as fuel } \\
\text { and calcined at } 550{ }^{\circ} \mathrm{C}\end{array}$ & $\begin{array}{l}\text { Dosage: } 0.05 \mathrm{mg} \text {, volume: } 25 \mathrm{~mL} \text {, } \\
\text { pH: } 4 \text {, temperature: } 25^{\circ} \mathrm{C}\end{array}$ & 21.5 & $\mathrm{~L}$ & PSO & (52) \\
\hline $\begin{array}{l}\text { Magnesium oxide }(\mathrm{MgO}) \\
\text { synthesized using oxalic acid as fuel } \\
\text { and calcined at } 800^{\circ} \mathrm{C}\end{array}$ & $\begin{array}{l}\text { Dosage: } 0.05 \mathrm{mg} \text {, volume: } 25 \mathrm{~mL} \text {, } \\
\mathrm{pH}: 4 \text {, temperature: } 25^{\circ} \mathrm{C}\end{array}$ & 18.1 & $\mathrm{~L}$ & PSO & $(52)$ \\
\hline $\begin{array}{l}\text { Magnesium oxide }(\mathrm{MgO}) \\
\text { synthesized using citric acid as fuel } \\
\text { and calcined at } 800{ }^{\circ} \mathrm{C}\end{array}$ & $\begin{array}{l}\text { Dosage: } 0.05 \mathrm{mg} \text {, volume: } 25 \mathrm{~mL} \text {, } \\
\text { pH: } 4 \text {, temperature: } 25^{\circ} \mathrm{C}\end{array}$ & 16.5 & $\mathrm{~L}$ & PSO & $(52)$ \\
\hline $\mathrm{SnO}_{2} /\left(\mathrm{NH}_{4}\right)_{2}-\mathrm{SnCl}_{6}-\mathrm{NCs}-\mathrm{AC}$ & $\begin{array}{l}\text { Dosage: } 0.015 \mathrm{~g}, \text { volume: } 50 \mathrm{~mL} \text {, } \\
\mathrm{pH}: 6 \text {, concentration: } 10 \mathrm{mg} / \mathrm{L}\end{array}$ & 83.34 & $\mathrm{~L}$ & PSO & (46) \\
\hline $\begin{array}{l}\text { Rice husk char (RHC) modified } \\
\text { using KOH (KMRHC) }\end{array}$ & $\begin{array}{l}\text { Dosage: } 2 \mathrm{~g} / \mathrm{L}, \mathrm{pH}: 4, \\
\text { concentration: } 80 \mathrm{mg} / \mathrm{L} \text {, } \\
\text { temperature: } 303 \mathrm{~K} \text {, agitation } \\
\text { speed: } 250 \mathrm{rpm}\end{array}$ & 38.8 & $\mathrm{~L}$ & PSO & (36) \\
\hline$\gamma$-alumina & $\begin{array}{l}\text { Dosage: } 1 \mathrm{~g} / \mathrm{L}, \mathrm{pH}: 2.5 \\
\text { concentration: } 50 \mathrm{mg} / \mathrm{L} \\
\text { temperature: } 303 \mathrm{~K}\end{array}$ & 50.1 & $\mathrm{~L}$ & PSO & (72) \\
\hline $\begin{array}{l}\text { Activated carbon prepared using } \\
\text { raw coffee ground }\end{array}$ & $\begin{array}{l}\text { Dosage: } 50 \mathrm{mg} \text {, volume: } 50 \mathrm{~mL} \text {, } \\
\text { concentration: } 25 \mathrm{mg} / \mathrm{L} \text {, } \\
\text { temperature: } 318 \mathrm{~K}\end{array}$ & 100 & $\mathrm{~L}$ & PSO & (44) \\
\hline Ungrafted chitosan & $\begin{array}{l}\text { Dosage: } 0.1 \mathrm{~g} \text {, concentration: } 50 \\
\mathrm{mg} / \mathrm{L}, \mathrm{pH} 5\end{array}$ & 1.7 & $\mathrm{~L}$ & PSO & (73) \\
\hline Grafted chitosan (cts(x)-g-PNVP) & $\begin{array}{l}\text { Dosage: } 0.1 \mathrm{~g} \text {, concentration: } 50 \\
\mathrm{mg} / \mathrm{L}, \mathrm{pH} 3\end{array}$ & 63.7 & $\mathrm{~L}$ & PSO & (73) \\
\hline $\begin{array}{l}\text { Quaternary ammonium group-rich } \\
\text { magnetic nanoparticles (MNPs), } \\
\mathrm{Fe}_{3} \mathrm{O}_{4} @ \mathrm{SiO}_{2}-\mathrm{MPS} \text {-g-DAC (FSMD) }\end{array}$ & $\begin{array}{l}\text { Dosage: } 10 \mathrm{mg} \text {, volume: } 10 \mathrm{~mL} \text {, } \\
\text { concentration: } 200 \mathrm{mg} / \mathrm{L}, \mathrm{pH}: 3 \text {, } \\
\text { shaking speed: } 200 \mathrm{rpm}, \\
\text { temperature: } 318 \mathrm{~K}\end{array}$ & 109.1 & $\mathrm{~L}$ & PSO & (66) \\
\hline Crossed-linked porous polyimide & $\begin{array}{l}\text { Dosage: } 2 \mathrm{mg}, \text { volume: } 10 \mathrm{~mL}, \\
\text { temperature: } 298 \mathrm{~K}, \mathrm{pH}: 3\end{array}$ & 833.33 & $\mathrm{~L}$ & PSO & (74) \\
\hline $\begin{array}{l}\text { Polyaniline coated almond shell } \\
\text { (PANI@AS) }\end{array}$ & $\begin{array}{l}\text { Dosage: } 0.5 \mathrm{~g} / \mathrm{L} \text {, concentration: } 50 \\
\mathrm{mg} / \mathrm{L} \text {, pH: } 5\end{array}$ & 190.98 & $\mathrm{~F}$ & PSO & (35) \\
\hline
\end{tabular}

Key: L = Langmuir, F = Freundlich, $\mathrm{T}=$ Temkin, $\mathrm{RP}=$ Redlich-Peterson, $\mathrm{NLL}=$ Non-linear Langmuir, PFO = Pseudo first order, PSO = Pseudo second order 


\section{Limitations}

The use of physical adsorption has been highly recognized as an effective wastewater remediation method due to its promising properties. Notwithstanding, certain issues still need to be addressed. For instance, adsorbent capacity progressively deteriorates as the number of cycles increases, and the spent adsorbent may be considered as hazardous waste. Furthermore, the risk of explosion between contaminants and adsorbents also exists (75).

\section{Conclusions and future perspectives}

The present study showed various adsorbents that have been used by numerous researchers in the treatment of wastewater contaminated by OG dye. Based on the literature survey, it is clear that adsorption of OG dye can be achieved using different materials such as activated carbons, biomass, layered double hydroxides, polymers, clays, metal oxides and many others. Although pristine adsorbents were found to effective, however, various researchers have modified pristine adsorbents using different approaches for better removal efficiency. Most studies have reported high removal efficiency at low $\mathrm{pH}$ values and low removal efficiency at high $\mathrm{pH}$ values. The OG dye removal process in most cases was found to follow the Langmuir isotherm. Moreover, the kinetics data for the adsorption of OG dye onto various adsorbents, usually follows the pseudo-second-order kinetics model, and the adsorption capacity ranged from $0.24-1452.07 \mathrm{mg} / \mathrm{g}$. Finally, based on the information compiled, adsorption is an effective technique for the removal of OG dye from aqueous solutions, and various low-cost and abundantly available materials including biomass, clays and industrial wastes have shown good capability for the removal of OG dye. Notwithstanding, to promote the industrial application of adsorption technique, future researches are encouraged to focus on the use of immobilized adsorbents due to their convenient recovery. Also, mixed pollutant effluents should be used in assessing the capacity of adsorbents. In addition, most researches are usually conducted in a laboratoryscale using synthetic wastewater. Thus, much attention should be given to treating real wastewater samples via adsorption techniques. Moreover, it is essential to assess the ecotoxicity of various adsorbents before their widespread application.

\section{Ethical issue}

Authors are aware of, and comply with, best practice in publication ethics specifically with regard to authorship (avoidance of guest authorship), dual submission, manipulation of figures, competing interests and compliance with policies on research ethics. Authors adhere to publication requirements that submitted work is original and has not been published elsewhere in any language.

\section{Competing interests}

The authors declare that there is no conflict of interest that would prejudice the impartiality of this scientific work.

\section{Authors' contribution}

All authors of this study have a complete contribution for data collection, data analyses and manuscript writing.

\section{References}

1. Imam SS, Adnan R, Kaus NHM. Immobilization of BiOBr into cellulose acetate matrix as hybrid film photocatalyst for facile and multicycle degradation of ciprofloxacin. Journal of Alloys and Compounds. 2020:155990.
2. Garba ZN, Zango ZU, Babando A, Galadima A. Competitive adsorption of dyes onto granular activated carbon. J Chem Pharm Res. 2015;7:710-7.

3. Ghosh JP, Achari G, Langford CH. Design and evaluation of a UV LED photocatalytic reactor using anodized $\mathrm{TiO} 2$ nanotubes. Water Environment Research. 2016;88(8):785-91.

4. Gan G, Liu J, Zhu Z, Yang Z, Zhang C, Hou X. A novel magnetic nanoscaled $\mathrm{Fe} 3 \mathrm{O} 4 / \mathrm{CeO} 2$ composite prepared by oxidationprecipitation process and its application for degradation of orange $\mathrm{G}$ in aqueous solution as Fenton-like heterogeneous catalyst. Chemosphere. 2017;168:254-63.

5. Kyriakopoulos J, Kordouli E, Bourikas K, Kordulis C, Lycourghiotis A. Decolorization of Orange-G aqueous solutions over C60/MCM-41 photocatalysts. Applied Sciences. 2019;9(9):1958.

6. Abdelkader NB-H, Bentouami A, Derriche Z, Bettahar N, De Menorval L-C. Synthesis and characterization of $\mathrm{Mg}-\mathrm{Fe}$ layer double hydroxides and its application on adsorption of Orange $\mathrm{G}$ from aqueous solution. Chemical Engineering Journal. 2011;169(1-3):231-8.

7. Dulman V, Cucu-Man S-M, Bunia I, Dumitras M. Batch and fixed bed column studies on removal of Orange $G$ acid dye by a weak base functionalized polymer. Desalination and Water Treatment. 2016;57(31):14708-27

8. Dulman V, Cucu-Man SM, Olariu RI, Buhaceanu R, Dumitraș M, Bunia I. A new heterogeneous catalytic system for decolorization and mineralization of Orange $\mathrm{G}$ acid dye based on hydrogen peroxide and a macroporous chelating polymer. Dyes and Pigments. 2012;95(1):79-88.

9. Wang Y, Priambodo R, Zhang H, Huang Y-H. Degradation of the azo dye Orange $\mathrm{G}$ in a fluidized bed reactor using iron oxide as a heterogeneous photo-Fenton catalyst. RSC Advances. 2015;5(56):45276-83.

10. Singh J, Uma SB, Sharma YC. A Very Fast Removal of Orange G from its Aqueous Solutions by Adsorption on Activated Saw Dust: Kinetic Modeling and Effect of Various Parameters. Rem. 2012;5(10):15

11. Pereira GF, El-Ghenymy A, Thiam A, Carlesi C, Eguiluz KI, Salazar-Banda GR, et al. Effective removal of Orange-G azo dye from water by electro-Fenton and photoelectro-Fenton processes using a boron-doped diamond anode. Separation and Purification Technology. 2016;160:145-51

12. Li Y, Yang Z, Zhang H, Tong X, Feng J. Fabrication of sewage sludge-derived magnetic nanocomposites as heterogeneous catalyst for persulfate activation of Orange $G$ degradation Colloids and Surfaces A: Physicochemical and Engineering Aspects. 2017;529:856-63.

13. Tarkwa J-B, Oturan N, Acayanka E, Laminsi S, Oturan MA Photo-Fenton oxidation of Orange $\mathrm{G}$ azo dye: process optimization and mineralization mechanism. Environmental Chemistry Letters. 2019;17(1):473-9.

14. Arzani K, Ashtiani BG, Kashi AHA. Equilibrium and kinetic adsorption study of the removal of Orange-G dye using carbon mesoporous material. 无机材料学报. 2012;27(6).

15. Nassar MY, Ali AA, Amin AS. A facile Pechini sol-gel synthesis of $\mathrm{TiO} 2 / \mathrm{Zn} 2 \mathrm{TiO} 2 / \mathrm{ZnO} / \mathrm{C}$ nanocomposite: an efficient catalyst for the photocatalytic degradation of Orange $G$ textile dye. RSC Advances. 2017;7(48):30411-21.

16. Nassar MY, Mohamed TY, Ahmed IS, Mohamed NM, Khatab M Hydrothermally synthesized $\mathrm{Co} 3 \mathrm{O} 4, \alpha$-Fe $2 \mathrm{O} 3$, and $\mathrm{CoFe} 2 \mathrm{O}$ 4 nanostructures: efficient nano-adsorbents for the removal of Orange $\mathrm{G}$ textile dye from aqueous media. Journal of Inorganic and Organometallic Polymers and Materials. 2017;27(5):1526-37.

17. Jeon P, Park S-M, Baek K. Controlled release of iron for activation of persulfate to oxidize orange $\mathrm{G}$ using iron anode. Korean Journal of Chemical Engineering. 2017;34(5):1305-9.

18. Banerjee S, Chattopadhyaya MC, Chandra Sharma Y. Removal of an azo dye (Orange $G$ ) from aqueous solution using modified sawdust. Journal of Water, Sanitation and Hygiene for Development. 2015;5(2):235-43

19. Muthukumar M, Karuppiah MT, Raju GB. Electrochemical removal of CI Acid orange 10 from aqueous solutions. Separation and purification technology. 2007;55(2):198-205.

20. Birjandi N, Younesi H, Bahramifar N. Treatment of wastewater effluents from paper-recycling plants by coagulation process and 
optimization of treatment conditions with response surface methodology. Applied Water Science. 2016;6(4):339-48.

21. Wang Z, Huang W, Yang G, Liu Y, Liu S. Preparation of cellulosebase amphoteric flocculant and its application in the treatment of wastewater. Carbohydrate polymers. 2019;215:179-88.

22. Znad H, Al Ketife AM, Judd S, AlMomani F, Vuthaluru HB Bioremediation and nutrient removal from wastewater by Chlorella vulgaris. Ecological Engineering. 2018;110:1-7.

23. Yusoff MAM, Imam SS, Shah I, Adnan R. Photocatalytic activity of bismuth oxyiodide nanospheres and nanoplates in the degradation of ciprofloxacin under visible light. Materials Research Express. 2019;6(8):0850g5.

24. Imam SS, Panneerselvam P. Enhanced rhodamine B dye adsorption by groundnut shell activated carbon coated with $\mathrm{Fe} 3 \mathrm{O} 4$. Elixir Applied Chemistry. 2015;86:34984-9.

25. Şentürk İ, Alzein M. Adsorptive removal of basic blue 41 using pistachio shell adsorbent-Performance in batch and column system. Sustainable Chemistry and Pharmacy. 2020;16:100254

26. Saini J, Garg V, Gupta R, Kataria N. Removal of Orange G and Rhodamine B dyes from aqueous system using hydrothermally synthesized zinc oxide loaded activated carbon ( $\mathrm{ZnO}-\mathrm{AC})$. Journal of environmental chemical engineering. 2017;5(1):884-92.

27. Singh J, Banerjee S, Gusain D, Sharma YC. EQUILIBRIUM MODELLING AND THERMODYNAMICS OF REMOVAL OF ORANGE G FROM ITS AQUEOUS SOLUTIONS. Journal of Applied Sciences in Environmental Sanitation. 2011;6(3).

28. Cheung W, Szeto Y, McKay G. Intraparticle diffusion processes during acid dye adsorption onto chitosan. Bioresource technology. 2007;98(15):2897-904.

29. Bhatnagar A, Minocha A, Jeon B, Park J-M, Lee G. Adsorption of orange $\mathrm{G}$ dye on paper mill sludge: equilibrium and kinetic modeling. Fresenius Environmental Bulletin. 2007;16(9):1049-55.

30. Meetani M, Rauf M, Hisaindee S, Khaleel A, AlZamly A, Ahmad A. Mechanistic studies of photoinduced degradation of Orange $G$ using LC/MS. Rsc Advances. 2011;1(3):490-7.

31. Vinu R, Akki SU, Madras G. Investigation of dye functional group on the photocatalytic degradation of dyes by nano-TiO2. Journal of Hazardous Materials. 2010;176(1-3):765-73.

32. Hamous H, Khenifi A, Bouberka Z, Derriche Z, Hamous H, Khenifi A, et al. Electrochemical degradation of Orange $\mathrm{G}$ in $\mathrm{K} 2$ $\mathrm{SO} 4$ and $\mathrm{KCl}$ medium. Environmental Engineering Research. 2019;25(4):571-8

33. Kamimoto M. The Significance of Liquid Fuel Production from Woody Biomass. AIST TODAY. 2006.

34. Ari AG, Celik S. Biosorption potential of Orange $G$ dye by modified Pyracantha coccinea: Batch and dynamic flow system applications. Chemical engineering journal. 2013;226:263-70.

35. Hsini A, Essekri A, Aarab N, Laabd M, Addi AA, Lakhmiri R, et al. Elaboration of novel polyaniline@ Almond shell biocomposite for effective removal of hexavalent chromium ions and Orange $\mathrm{G}$ dye from aqueous solutions. Environmental Science and Pollution Research. 2020:1-14.

36. Malik A, Khan A, Humayun M. Preparation and chemical modification of rice husk char for the removal of a toxic dye (Orange G) from aqueous medium. Zeitschrift für Physikalische Chemie. 2019;233(3):375-92.

37. Banerjee S, Gautam RK, Jaiswal A, Gautam PK, Chattopadhyaya MC. Study on adsorption behavior of Acid Orange 10 onto modified wheat husk. Desalination and Water Treatment. 2016;57(26):12302-15.

38. Kumar S, Ahluwalia AS, Charaya MU. Adsorption of Orange-G dye by the dried powdered biomass of Chlorella vulgaris Beijerinck. Current Science. 2019;116(4):604.

39. Mohammed RA, Al-Mammar DE. Using Tobacco Leaves as Adsorbent for the Orange-G Dye Removal from its Aqueous Solutions. 2009

40. Guan Z, Lv J, Bai P, Guo X. Boron removal from aqueous solutions by adsorption-A review. Desalination. 2016;383:29-37.

41. Imam SS, Babamale HF. A Short Review on the Removal of Rhodamine B Dye Using Agricultural Waste-Based Adsorbents. Asian Journal of Chemical Sciences. 2020:25-37.

42. Habuda-Stanić M, Ravančić ME, Flanagan A. A review on adsorption of fluoride from aqueous solution. Materials. 2014;7(9):6317-66.
43. Arulkumar M, Sathishkumar P, Palvannan T. Optimization of Orange $G$ dye adsorption by activated carbon of Thespesia populnea pods using response surface methodology. Journal of hazardous materials. 2011;186(1):827-34.

44. Laksaci H, Khelifi A, Belhamdi B, Trari M. The use of prepared activated carbon as adsorbent for the removal of orange $\mathrm{G}$ from aqueous solution. Microchemical Journal. 2019;145:908-13.

45. Goswami M, Phukan P. Enhanced adsorption of cationic dyes using sulfonic acid modified activated carbon. Journal of Environmental Chemical Engineering. 2017;5(4):3508-17.

46. Jalali S, Rahimi MR, Ghaedi M, Asfaram A, Goudarzi A. Synthesis and characterization of $\mathrm{SnO} 2 /(\mathrm{NH} 4)$ 2-SnCl6 nanocomposites loaded on activated carbon and its application for adsorption of methylene Blue and Orange G. Applied Organometallic Chemistry. 2018;32(1):e3903.

47. Dawood GS. Removal Orange (G) Dye from aqueous solution by adsorption on Bentonite. Tikrit Journal of Pure Science. 2010;15(1):231-5

48. Jović-Jovičić N, Milutinović-Nikolić A, Banković P, Mojović Z, Žunić M, Gržetić I, et al. Organo-inorganic bentonite for simultaneous adsorption of Acid Orange 10 and lead ions. Applied Clay Science. 2010;47(3-4):452-6.

49. Salam MA, Kosa SA, Al-Beladi AA. Application of nanoclay for the adsorptive removal of Orange $G$ dye from aqueous solution. Journal of molecular liquids. 2017;241:469-77.

50. Mondal MK, Singh S, Umareddy M, Dasgupta B. Removal of Orange $\mathrm{G}$ from aqueous solution by hematite: Isotherm and mass transfer studies. Korean Journal of Chemical Engineering. 2010;27(6):1811-5.

51. Gusain D, Dubey S, Upadhyay SN, Weng CH, Sharma YC. Studies on optimization of removal of orange $G$ from aqueous solutions by a novel nano adsorbent, nano zirconia. Journal of Industrial and Engineering Chemistry. 2016;33:42-50.

52. Nassar MY, Mohamed TY, Ahmed IS, Samir I. MgO nanostructure via a sol-gel combustion synthesis method using different fuels: an efficient nano-adsorbent for the removal of some anionic textile dyes. J Mol Liq. 2017;225:730-40.

53. Daud M, Kamal MS, Shehzad F, Al-Harthi MA. Graphene/layered double hydroxides nanocomposites: a review of recent progress in synthesis and applications. Carbon. 2016;104:241-52.

54. Mishra G, Dash B, Pandey S. Layered double hydroxides: A brief review from fundamentals to application as evolving biomaterials. Applied Clay Science. 2018;153:172-86.

55. Zubair M, Daud M, McKay G, Shehzad F, Al-Harthi MA. Recent progress in layered double hydroxides (LDH)-containing hybrids as adsorbents for water remediation. Applied Clay Science. 2017;143:279-92.

56. Zhang L, Wang H, Yu W, Su Z, Chai L, Li J, et al. Facile and largescale synthesis of functional poly (m-phenylenediamine) nanoparticles by $\mathrm{Cu} 2+$-assisted method with superior ability for dye adsorption. Journal of Materials Chemistry. 2012;22(35):18244-51

57. Zhang L, Cheng Z, Guo X, Jiang X, Liu R. Process optimization, kinetics and equilibrium of orange $\mathrm{G}$ and acid orange 7 adsorptions onto chitosan/surfactant. Journal of Molecular Liquids. 2014;197:353-67.

58. Konaganti VK, Kota R, Patil S, Madras G. Adsorption of anionic dyes on chitosan grafted poly (alkyl methacrylate) s. Chemical engineering journal. 2010;158(3):393-401

59. Wu X-J, Wang J-D, Cao L-Q. Characterization and adsorption performance of chitosan/diatomite membranes for Orange G removal. e-Polymers. 2016;16(2):99-109.

60. Sandić ZP, Nastasović AB, Jović-Jovičić NP, Milutinović-Nikolić $\mathrm{AD}$, Jovanović DM. Sorption of textile dye from aqueous solution by macroporous amino-functionalized copolymer. Journal of Applied Polymer Science. 2011;121(1):234-42.

61. Xiao L, Xiong Y, Tian S, He C, Su Q, Wen Z. One-dimensional coordination supramolecular polymer $[\mathrm{Cu}$ (bipy)(SO4)] $\mathrm{n}$ as an adsorbent for adsorption and kinetic separation of anionic dyes. Chemical Engineering Journal. 2015;265:157-63.

62. Mall ID, Srivastava VC, Agarwal NK. Removal of Orange-G and Methyl Violet dyes by adsorption onto bagasse fly ash-kinetic study and equilibrium isotherm analyses. Dyes and pigments 2006;69(3):210-23. 
63. Mubarak N, Fo Y, Al-Salim HS, Sahu J, Abdullah E, Nizamuddin $\mathrm{S}$, et al. Removal of methylene blue and orange-G from waste water using magnetic biochar. International Journal of Nanoscience. 2015;14(04):1550009.

64. Anbia M, Hariri SA, Ashrafizadeh S. Adsorptive removal of anionic dyes by modified nanoporous silica SBA-3. Applied Surface Science. 2010;256(10):3228-33

65. Atia AA, Donia AM, Al-Amrani WA. Adsorption/desorption behavior of acid orange 10 on magnetic silica modified with amine groups. Chemical Engineering Journal. 2009;150(1):55-62.

66. Zheng X, Zheng H, Zhou Y, Sun Y, Zhao R, Liu Y, et al. Enhanced adsorption of Orange $G$ from aqueous solutions by quaternary ammonium group-rich magnetic nanoparticles. Colloids and Surfaces A: Physicochemical and Engineering Aspects. 2019;580:123746.

67. Greluk M, Hubicki Z. Effect of basicity of anion exchangers and number and positions of sulfonic groups of acid dyes on dyes adsorption on macroporous anion exchangers with styrenic polymer matrix. Chemical engineering journal. 2013;215:731-9.

68. Zhou L, Jin J, Liu Z, Liang X, Shang C. Adsorption of acid dyes from aqueous solutions by the ethylenediamine-modified magnetic chitosan nanoparticles. Journal of hazardous materials. 2011;185(2-3):1045-52.

69. Deng J-H, Zhang X-R, Zeng G-M, Gong J-L, Niu Q-Y, Liang J. Simultaneous removal of $\mathrm{Cd}$ (II) and ionic dyes from aqueous solution using magnetic graphene oxide nanocomposite as an adsorbent. Chemical Engineering Journal. 2013;226:189-200.

70. Budiman $\mathrm{H}$, Zuas O. Adsorption isotherm studies on acid orange10 dye removal using cerium dioxide nanoparticles. Indonesian Journal of Chemistry. 2014;14(3):226-32.

71. Wang T, Zhao P, Lu N, Chen H, Zhang C, Hou X. Facile fabrication of Fe3O4/MIL-101 (Cr) for effective removal of acid red 1 and orange $\mathrm{G}$ from aqueous solution. Chemical Engineering Journal. 2016;295:403-13.

72. Banerjee S, Dubey S, Gautam RK, Chattopadhyaya M, Sharma YC. Adsorption characteristics of alumina nanoparticles for the removal of hazardous dye, Orange $\mathrm{G}$ from aqueous solutions. Arabian Journal of Chemistry. 2019;12(8):5339-54.

73. Sutirman ZA, Sanagi MM, Abd Karim KJ, Naim AA, Ibrahim WAW. Enhanced removal of Orange G from aqueous solutions by modified chitosan beads: Performance and mechanism. International journal of biological macromolecules. 2019;133:1260-7.

74. Pan Z, Zhang X, Wang X. Adsorption of acid orange 10 on crosslinked porous polyimide. SN Applied Sciences. 2019;1(3):239.

75. Sharma S, Saxena R, Gaur G. Study of removal techniques for azo dyes by biosorption: a review. IOSR J Appl Chem. 2014;7:6-21. 